\title{
Importance of Motivational Factors among Fresh Graduate Employees
}

\author{
Sobia Shujaat \\ Department of Business Administration \\ Bahria University, Karachi \\ Pakistan \\ Farooq-E-Azam Cheema \\ Department of Business Administration \\ Bahria University, Karachi \\ Pakistan \\ Amir Manzoor \\ Department of Business Administration \\ Bahria University, Karachi \\ Pakistan
}

\begin{abstract}
Purpose: The current research is focused on analyzing the importance of motivational factors for newly graduated employees working in different organizations..

Methodology/Sampling: Primary data was gathered in the form of questionnaire survey from the selected respondents. The proposed study employed quantitative research technique. The study is exploratory in nature. 394 respondents were selected for the study including freshly graduated employees from different organizations. The data collected was analyzed statistically.

Findings: It was revealed from the study that there is significant impact of participation in decision-making and fair reward system on fresh graduates. However, there was no direct influence of monetary factors on fresh graduate motivation; nature of work and job description.

Practical Implications: The study is beneficial for human resource managers as it may help them in designing motivating jobs. Management can take into consideration factors that are important to motivate fresh graduates on job and then take actions in implementing them.
\end{abstract}

Keywords: Employee Motivation, Fresh Graduated Employees, Reward System, Decision Making.

JEL Classification: M12, M52, O15.

*The material presented by the authors does not necessarily portray the viewpoint of the editors and the management of the Institute of Business \& Technology (IBT).

* Sobia Shujaat: sobiashujaat@,bimcs.edu.pk

* Farooq-e-Azam Cheema: dr.live@live.com

* Amir Manzoor: amirmanzoor@bimcs.edu.pk

C JMSS is published by the Institute of Business and Technology (IBT). Main Ibrahim Hydri Road, Korangi Creek, Karachi-75190, Pakistan. 


\section{INTRODUCTION}

A large volume of global wealth is produced in the form of human capital. As a result, human resource management plays a central role in the process of increasing the effectiveness and efficiency of enterprises. The importance of employee motivation is manifested at all levels of the organization. In current scenario, managers have to be aware of the factors that motivate their subordinates to perform well, while employees require understanding about their job expectations. Human resource professionals have to assess the motivation need of employees; then design and implement an effective reward structure and systems for training and development to motivate them. Employer can only motivate workers by creating the conditions and environment that make people feel happy and satisfied to give their heart and soul to the job and the company (Frey \& Osterloch, 2002).

Within the workplace, (White, 1959) defines motivation as the variable that drives employees to (1) "want to act" and (2) "choose to act" to succeed in the workplace. Further, motivation is explained as the energy that encourages work-related behaviour and influences one's work style, direction, intensity and duration. There are two types of motivation at work, which stern from internal (intrinsic) and external (extrinsic) forces and are essential to production because they encourage employees to perform tasks. Internal motivation is very personal form of motivation and revolves around completing a task for the sake of self fulfilment. In this case, an employee completes a task early because it is rewarding to him, not because of a reward that might be earned. External motivation comes from other sources, including feedback from one's supervisor, team or company goal setting, and monetary rewards (Steers et al. 2004).

It seems obvious that companies require motivated employees hence motivation becomes certainly an important aspect of human resource management. However, due to the complex nature of human behavior, it is not easy to understand the motivation need of employees.

Although Seongsin (2007) argued that money is not as convincing as it seems, companies try to implement monetary incentives to motivate employees as their primary tool. Performance-based remuneration was the new anthem, which was used without question by the companies. Recently as a result of the financial crisis, many large and small companies have cut down their costs by reducing wages and bonuses for staff; however questions have been raised to investigate whether there are other options to motivate employees to be more cost effective and efficient.

This research aims to study the motivational factors for freshly graduated employees. It analyses the difference in work motivation for fresh graduates, their work priorities, and determination for the future job seeking. It would also take into consideration the gender sensitivity with respect to motivational factors.

\subsection{Research Hypothesis}

$\mathrm{H}_{1}$ : There is a significant impact of monetary factors on fresh graduates' motivation.

$\mathrm{H}_{2}$ : Nature of work and job description is more important than remuneration for motivating fresh graduates. 
$\mathrm{H}_{3}$ : Fair rewards and recognition system is more important than remuneration for motivating fresh graduates.

$\mathrm{H}_{4}$ : Participation in decision-making and greater responsibility has significant positive impact on motivation level of fresh graduates.

\section{LITERATURE REVIEW}

The task performance element of motivation is based upon whether the individual can actually perform job expectations. This includes mental and physical capacities and although an individual may be motivated, if that individual cannot perform the job to begin with, the motivation will not take him or her as far as he or she needs to go. Organisations seek to fill this performance gap not only by making good organisational hires, but also by initiating workplace training. Due to the fact that individuals respond differently to situations and view things from different perspectives, it is not surprising that the factors that influence job satisfaction are quite extensive (Glebbeek \& Bax, 2004).

Some researchers have spent most of their life studying the responses of employees (Kovach, 1980, Employee motivation). The results showed that the importance of motivational factors may differ in certain groups of people. However, there are several motivating factors; such as promotion on the job, Interesting work, full appreciation of work done, feel well informed and involved in organizational process and decision making, and good wages are the factors that received high rating in numerous surveys about the motivational factors (Luthans \& Stajkovic, 2000).

Employees must be empowered to take action based on the basis of their understanding of different situations and scenarios within the organization. This empowerment will develop their problem solving skill and they will become a part of the big picture. Whether employees are working individually or they are part of the cross-functional teams, HR departments and organizations today give employees the freedom and responsibility of making independent decisions. There have been many examples when employees have risen through the ranks reaching top management positions. "Michael Smith, general manager of the Hyatt Regency Crystal City began bussing tables at the Hyatt in Winston-Salem, N.C., while majoring in business administration in college. He worked his way through the ranks of the food and beverage sector of the Hyatt organization, honing his skills as a room service waiter, then an executive steward" (White 1959).

Today, the concept of career planning or guiding them to achieve their personal goal has also gained tremendous importance in organizations. So, it's not just about having strong talented candidates for employees but it also involves engaging them in activities for a future position. "As organizations escalate the war for talent, pay and programs are at risk of becoming commodities. They're relatively easy to duplicate." (Taylor 2002)

In today's environment organizations that do not bind employees with a shared vision fail to nurture a healthy work environment. The organization and its standing should be sound enough to make employees feel that they are a part of a better organization. If their association feeling is good then they would work towards its betterment more. The organization should provide such culture, values and image of the brand in such a positive way that creates positive influence on employees. This "We have to provide employees with adequate training and the best available tools to get their job done. We have to 
instill in them the pride of being an employee, the pride of being in the organization, the pride of doing any job in the absolute best manner possible" (Wilson, 2000)

Lim et al. (2008) in their research 'Money motives, achievement orientation, and motivation to work among youths' found that the attitudes of pre -existing work before entering the workforce should be the basis for people to serve their future work settings . Therefore, if companies have knowledge of the factors that students have appreciated regarding work, they will be able to attract more people. This resulted in a greater number of applications and the selection of candidates.

Therefore, the attitudes of students towards motivating factors could be predictors of attitudes at work in the future. This means that advertisers not only have an advantage of the research results in this work, but also administrators who deal with newly graduated employees. Therefore, new graduates job prospects are believed to be self-reflective about the factors that are motivating for them at work, positively influence the choice of a company and a position that request. The perfect combination between the expectations of students can be used in motivational factors and motivation of business strategy, resulting in better performance and student satisfaction when they go to make their first big step in the race (Oldham \& Hackman, 2010).

Krause (1989) found that the working configuration before entering workforce developed as a basis for individuals to serve in their future work settings. Further support for this approach comes from Ajzen (1991) theory of planned behavior. It is said that intentions to perform behaviors attitudes toward these behaviors can be predicted. Anthropological studies (McCall and Lawler, 1976) showed that the positions are developed before entering the labor market.

The impact of culture and gender in work goals among business students in Canada and China were analyzed by Bu \& McKeen (2001) in their research articles of "Work goals among male and female business students in Canada and China". Significant differences were found between these two groups. Chinese students showed weaker concern for a balanced life and more interested in rewards fundamental / intrinsic routine and moral consistency. His attention on extrinsic rewards and organizational influence are the same compared to Canadian students' attention. Another comparison of students from different countries was Sagan, Tomkiewicz, Adeyemi - which focuses on students from Poland and Russia. They found that students in Poland showed greater intrinsic preference while Russian students had a higher preference for extrinsic factors. Finally, there is research that focused exclusively on students and their attitude to work as predictors of future job motivation (Frey \& Osterloch, 2002).

Sonawane (2008) highlighted "full appreciation of work done", "sense of responsibility" and "interesting work" as the main motivating factors for employees. Sharma (1989) found that the benefits of effective safety and have been recognized as the most important by Indian workers. It was believed that's there was a fundamental correlation between employee motivation that led to employee job satisfaction, resulting higher quality and committed workforce which then led to improved companies performance and profitability (McClelland, 1968). Kinnear \& Sutherland (2000) showed that financial reward and recognition was the motivator ranked first. Knowledge workers were also strongly influenced by the freedom to act, independent development opportunities motivated and have access to new technologies (Kovach, 1995, Employee motivation). Good working conditions are also of key interest to future business persons in various organizations (Ajzen, 1991; 
Allender \& Allender, 1998). Perhaps it is recommended that there should be also an opportunity for promotion and sensitive authority from senior management (Armstrong \& Murlis, 2004). Employee retention is defined as a systematic attempt by employers to create and maintain a workplace that encourages employees to stay in the organization, by providing them with policies and practices that address their diverse needs and keeps them motivated. It is believed that a competitive compensation and benefits package initiates employee retention, as in it plays a crucial part in facilitating employers to attract and engage the amount of employees that they wish to retain. Moreover, various factors that enhance employee commitment and satisfaction include a fair compensation with respect to the employee's value contributions to the organization, providing of feedback, an opportunity to learn and grow, a positive work environment, and most importantly, recognition for the uniqueness of each individual's competencies to keep employees well motivated and productive. Furthermore, it was identified by Also, Griffeth et al. (2000) high performers of any firm are most likely seek employment elsewhere if they are inadequately rewarded.

\section{RESEARCH METHOD}

Primary data has been collected through use of questionnaire survey from the selected respondents to acquire the required information about the understudy variables. This involved quantitative research approach and the study is exploratory in nature. Convenience based sampling was used as a technique to gather data from respondents from a sample of 394 respondents, which is considered to be sufficient for an unknown population. All variables were measured on a five-point Likert-type scale, ranging from 1 (strongly disagree) to 5 (strongly agree). The data attained after employing quantitative research methods was analyzed by using SPSS software. The control variables include firm type and firm capital. Firm type was measured by the type of industry, including real estate, finance, industrial product, resource, technology, consumer product, service and agriculture and food industry. Likewise, firm capital was measured by the capital invested by the company. To find the significant influence of independent motivational factors on newly graduated employees' motivation, regression analysis was applied in the form of Multiple Linear Regression (MLR). With the help of MLR, it is easy to identify the linear relationship between the independent and dependent variable as explained in the linear equation. Independent sample test was applied to test the hypotheses, using the SPSS software. Descriptive statistics and linear regression is used to find out the significant impact of independent variables on dependent variables.

The following research model explains the expected relationship between the understudy variables.

Fresh Graduate Motivation $=\alpha+\beta_{1}$ (Monetary Factors) $+\beta_{2}$ (Nature of Work $)+\beta_{3}$ (Rewards System) $+\beta_{4}($ Decision Making) 


\section{FINDINGS AND INTERPRETATION OF THE RESULTS}

Table 1

Reliability Statistics

\begin{tabular}{|l|l|}
\hline Cronbach's Alpha & N of Items \\
\hline .837 & 17 \\
\hline
\end{tabular}

As shown in Table 1 , the data is reliable for statistical analysis because the reliability range of Cronbach's Alpha is 0.837 which falls between 0.6 to 0.9 .

Table 2

Model Summary

\begin{tabular}{|l|l|l|l|l|}
\hline Model & R & R Square & Adjusted R Square & Std. Error of the Estimate \\
\hline 1 & $.476^{\mathrm{a}}$ & .227 & .215 & 1.173 \\
\hline
\end{tabular}

a. Predictors: (Constant), There is fair reward and recognition policy in my organization., Job description of fresh graduates includes have more interesting work as compared to old employees? , Fresh graduates are provided with the enough work?, On the basis of performance, opportunity for promotion exists in your organization for fresh graduates., Ideas and views of fresh graduates are welcomed for decision making?, Fresh graduates are offered good remuneration packages?

Table 2, Model summary table, explains the relationship between regression model and dependent variable of study. It can be seen from the model summary that the value of $\mathrm{R}^{2}$ is 0.227 , which means that 22.7 percent of the total variance has been explained. The value of $\mathrm{R}$ (Multi correlation coefficient) explains the variation in the model due to dependent variable also regarded as control of dependent variable in the model, which is favorable for the significance of test. Here the value of $\mathrm{R}$ is 0.476 .

Table 3

ANOVA

\begin{tabular}{|ll|l|l|l|l|l|}
\hline Model & Sum of Squares & Df & Mean Square & F & Sig. \\
\hline 1 & Regression & 154.861 & 6 & 25.810 & 18.743 & $.000^{\mathrm{a}}$ \\
& Residual & 527.405 & 383 & 1.377 & & \\
Total & 682.267 & 389 & & & \\
\hline
\end{tabular}

a. Predictors: (Constant), There is fair reward and recognition policy in my organization., Job description of fresh graduates includes have more interesting work as compared to old employees? , Fresh graduates are provided with the enough work?, On the basis of performance, opportunity for promotion exists in your organization for fresh graduates., Ideas and views of fresh graduates are welcomed for decision making?, Fresh graduates are offered good remuneration packages?

b. Dependent Variable: Fresh graduates are self motivated and focused on their job?

The ANOVA (Analysis of Variance) table analyzes the significance of regression model to check whether the regression model is significant (valid) or insignificant. The result is finalized on the basis of sig-value present in the right hand side last column. The test has been applied on $95 \%$ level of confidence and for the significance of regression model the test 
value should fall in the 5\% level of significance. In the above Table 3 , the regression model is significant at 0.000 .

Table 4

Coefficients

\begin{tabular}{|c|c|c|c|c|c|}
\hline & \multicolumn{2}{|c|}{ Unstandardized Coefficients } & \multirow{2}{*}{$\begin{array}{l}\text { Standardized } \\
\text { Coefficients } \\
\text { Beta }\end{array}$} & \multirow[b]{2}{*}{$\mathrm{t}$} & \multirow[b]{2}{*}{ Sig. } \\
\hline Model & B & Std. Error & & & \\
\hline (Constant) & 1.093 & .280 & & 3.908 & .000 \\
\hline $\begin{array}{l}\text { Fresh graduates are offered good } \\
\text { remuneration packages? }\end{array}$ & .006 & .054 & .005 & .102 & .919 \\
\hline $\begin{array}{l}\text { Fresh graduates are provided with the } \\
\text { enough work? }\end{array}$ & -.060 & .051 & -.057 & -1.174 & .241 \\
\hline $\begin{array}{l}\text { Job description of fresh graduates } \\
\text { includes have more interesting work as } \\
\text { compared to old employees? }\end{array}$ & .098 & .056 & .091 & 1.743 & .082 \\
\hline $\begin{array}{l}\text { Ideas and views of fresh graduates are } \\
\text { welcomed for decision making? }\end{array}$ & .156 & .051 & .150 & 3.035 & .003 \\
\hline $\begin{array}{l}\text { On the basis of performance, } \\
\text { opportunity for promotion exists in } \\
\text { your organization for fresh graduates. }\end{array}$ & .025 & .057 & .021 & .445 & .657 \\
\hline $\begin{array}{l}\text { There is fair reward and recognition } \\
\text { policy in my organization. }\end{array}$ & .434 & .049 & .417 & 8.873 & .000 \\
\hline
\end{tabular}

a. Dependent Variable: Fresh graduates are self motivated and focused on their job?

After prove of significant of regression model through ANOVA table we further move to the last table of coefficients. Hypothesis results are based on above table. In Table 4, independent variables are present with their beta and sig values; beta values predict the degree of relationship with the dependent variable while sig-values represent the significance of relationship. In this table the individual relationship of dependent variable and independent variable is explained. In relationship with fresh graduated motivation; remuneration and salary packages has an insignificant relationship (0.919), work provided is also insignificant (0.241), job description including interesting work (0.082), while participation in decision making has a significant impact (0.003) and fair reward system has also a significant impact on fresh graduates motivation (0.000).

Table 5

Frequency Tables

(On the basis of performance, opportunity for promotion exists in your organization for fresh graduates)

\begin{tabular}{|ll|l|l|l|l|}
\hline & Frequency & Percent & Valid Percent & Cumulative Percent \\
\hline Valid & Strongly Agree & 26 & 6.6 & 6.6 & 6.6 \\
Agree & 91 & 23.1 & 23.1 & 29.7 \\
Neutral & 71 & 18.0 & 18.0 & 47.7 \\
Disagree & 170 & 43.1 & 43.1 & 90.9 \\
Strongly Disagree & 36 & 9.1 & 9.1 & 100.0
\end{tabular}

IBT Journal of Business Studies (Formerly Journal of Management \& Social Sciences) 
(On the basis of performance, opportunity for promotion exists in your organization for fresh graduates)

\begin{tabular}{|ll|l|l|l|l|}
\hline & Frequency & Percent & Valid Percent & Cumulative Percent \\
\hline Valid & Strongly Agree & 26 & 6.6 & 6.6 & 6.6 \\
& 91 & 23.1 & 23.1 & 29.7 \\
Agree & 71 & 18.0 & 18.0 & 47.7 \\
Neutral & 170 & 43.1 & 43.1 & 90.9 \\
Disagree & 36 & 9.1 & 9.1 & 100.0 \\
Strongly Disagree & 394 & 100.0 & 100.0 & \\
Total & & & &
\end{tabular}

Fresh graduates are self-motivated and focused on their job?

\begin{tabular}{|c|c|c|c|c|c|}
\hline & & Frequency & Percent & Valid Percent & Cumulative Percent \\
\hline \multirow[t]{6}{*}{ Valid } & Strongly Agree & 47 & 11.9 & 12.0 & 12.0 \\
\hline & Agree & 91 & 23.1 & 23.2 & 35.1 \\
\hline & Neutral & 34 & 8.6 & 8.7 & 43.8 \\
\hline & Disagree & 150 & 38.1 & 38.2 & 81.9 \\
\hline & Strongly Disagree & 71 & 18.0 & 18.1 & 100.0 \\
\hline & Total & 393 & 99.7 & 100.0 & \\
\hline Missing & System & 1 & .3 & & \\
\hline Total & & 394 & 100.0 & & \\
\hline
\end{tabular}

There is fair reward and recognition policy in my organization.

\begin{tabular}{|c|c|c|c|c|c|}
\hline & & Frequency & Percent & Valid Percent & Cumulative Percent \\
\hline \multirow[t]{6}{*}{ Valid } & Strongly Agree & 40 & 10.2 & 10.2 & 10.2 \\
\hline & Agree & 75 & 19.0 & 19.2 & 29.4 \\
\hline & Neutral & 47 & 11.9 & 12.0 & 41.4 \\
\hline & Disagree & 154 & 39.1 & 39.4 & 80.8 \\
\hline & Strongly Disagree & 75 & 19.0 & 19.2 & 100.0 \\
\hline & Total & 391 & 99.2 & 100.0 & \\
\hline Missing & System & 3 & .8 & & \\
\hline Total & & 394 & 100.0 & & \\
\hline
\end{tabular}

The above frequency distribution tables explain the frequency of responses given by selected sample of 394 respondents during the survey. Above tables shows the level of agreement and disagreements form the statements given in questionnaire in terms of their percentage analysis. 


\section{Figure 1}

Frequency Response for Existence of Performance-Based Opportunity

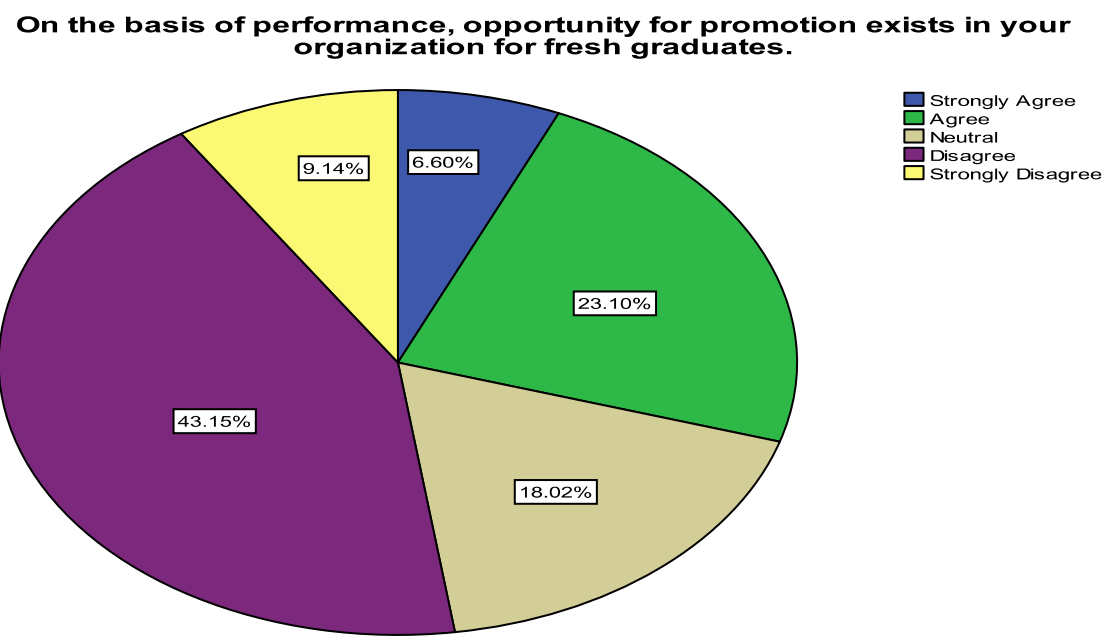

The above pi-chart shows the graphical presentation of frequency of responses in terms of percentage. For example, as we can identify that $43.15 \%$ respondents disagree with the statement that opportunity of promotion exists in their organization for fresh graduates on the basis of performance.

Figure 3

Frequency Response for Self-Motivation and Job Focus

Fresh graduates are self motivated and focused on their job?

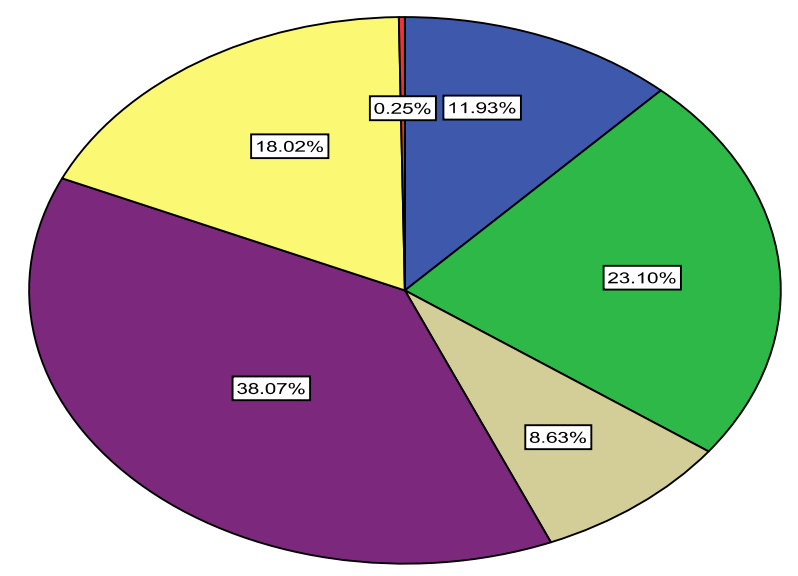

Strongly Agree Deutral Disagree Strongly Disagree 


\section{Figure 4}

Frequency Response for Fair Reward and Recognition Policy

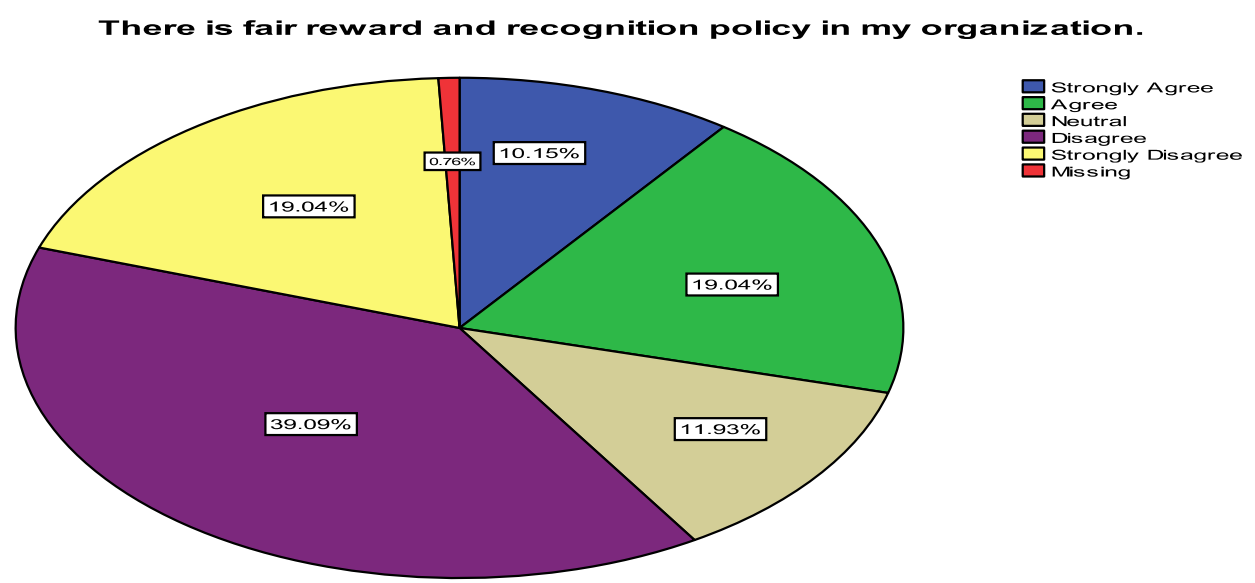

As indicated in pie-charts, $38.07 \%$ respondents strongly agreed that they are self motivated and focus on their jobs. Majority of respondents agreed that there exist a fair reward and recognition policy in their organization.

\section{CONCLUSION AND RECOMMENDATIONS}

There is significant impact of participation in decision making and fair reward system on employees' motivation, however there is no direct influence of monetary factors on fresh graduates' motivation; nature of work and job description also remained insignificant. Today, two of the greatest challenges facing organizations in Pakistan are the intensifying competitive atmosphere and the continuous increase in employees' expectations in terms of better employee retention plans.

\subsection{Recommendations}

Organizations should provide employees out of routine, challenging and meaningful work so that they able to think out of box. Similarly when employees are engaged in the meaningful work they have a sense of accomplishment that they are being valued and enjoy the achievement of the set goal. Managers should engage their subordinates in challenging work task and help employee to avoid boredom in the work place. They should delegate authority and involve employees at all levels in decision making process so that they all gets equal chances to participate. This will make the newly inducted graduates feel valued and can lead to high level of motivation among them. HR departments must design a fair reward system for motivating fresh graduated employees so they perform efficiently at their work place. 


\section{REFERENCES}

Ajzen, I. (1991) The theory of planned behavior. Organizational Behavior and Human Decision Processes, vol. 50, p.179-211.

Allender, H., \& Allender, J. (1998) Identifying the right management job for you. Industrial Management, Mar/Apr98, vol. 40, no.2, p.29-31.

Armstrong, M., \& Murlis, H. (2004) Reward management: A handbook of remuneration strategy and practice. London: Kogan Page.

Bu, N., \& Mckeen, C. (2001) Work goals among male and female business students in Canada and China: the effects of culture and gender. International Journal of Human Resource Management, vol. 12, no.2, p.166-183.

Frey, B., \& Osterloch, M. (2002).Successful Management by Motivation - Balancing Intrinsic and Extrinsic Incentives. Zurich: Springer.

Glebbeek, AC., \&Bax, EH. (2004). Is high employee turnover really harmful? An empirical test using company records. Academy of Management Journal, vol.47, p. 277-286.

Griffeth R. W.,Hom P. W. \& Gaertner S. (2000) A Meta-analysis of antecedents and correlates of employee turnover: update, moderator tests, and research implications for the next millennium, Journal of management, vol.26. no.3.

Herzberg, F. (1968). One more time: How do you motivate employees? Harvard Business Review, vol. 46, no.1, p.53-63.

Kinnear, L., \& Sutherland, M. (2000) Determinants of organizational commitment amongst knowledge workers. South African Journal of Business Management, vol. 31 no.3, p.106-113.

Kinnear, L., \& Sutherland, M. (2000) Determinants of organizational commitment amongst knowledge workers. South African Journal of Business Management, vol.31 no.3, 106-113.

Kovach, K. (1980) Why motivational theories don't work. Advanced Management Journal, vol.45, no.2, p.54-60.

Kovach, K. (1995) Employee motivation: Addressing a crucial factor in you organization's performance. Employment Relations Today, vol. 22, no.2, p.93-107.

Krause, P. (1992) The battle for homestead, 1880-1892: Politics, culture, and steel. Pittsburgh, PA: Pittsburgh University Press.

Lim, V., Srivastava, A., \& Si Sng, Q. (2008) Money motives, achievement orientation, and motivation to work among youths. Journal of International Business and Economics, vol. 8, no 3, p.104-111.

Lindner, J. (1998) Understanding Employee Motivation. Journal of Extension, vol.36, no.3, Research in Brief, www.joe.org, visited December 7th 2012.

Lu, L. (1999) Work Motivation, Job Stress and Employees' Well-being. Journal of Applied Management Studies, vol. 8, no.1, p.61-63.

Luthans, F., \& Stajkovic, A. (2000) The Impact of Recognition on Employee Performance http://www.sba.muohio.edu/management/MWAcademy/2000/, visited December, 7th 2012.

McClelland, D. (1968) Money as a motivator - Some research insights. The McKinsey Quarterly, Feb68, Vol. 57 Issue 2, p.23-28.

McClelland, D. (1968). Money as a motivator - Some research insights. The McKinsey Quarterly, vol. 57, no.2, p.23-28.

McCall, M., \& Lawler, E. (1976) High School Students' Perceptions of Work. Academy of Management Journal, vol. 19, no.1, p.17-24.

Oldham, G., \& Hackman, R. (2010) Not what it was and not what it will be: The future of

IBT Journal of Business Studies (Formerly Journal of Management \& Social Sciences) 
job design research. Journal of Organizational Behavior, vol. 3, no. 2/3, p.463-479.

Sagan, M., Tomkiewicz, J., Adeyemi-Bello, T., \& Frankel, R. (2008) Importance of Job Characteristics among Future Businesspersons: A Comparative Study of Russian and Polish Students. International Journal of Management, vol. 25, no.4, p.641-653.

Seongsin, L. (2007) Vroom's expectancy theory and the public library customer motivation model, Library Review, vol. 56 no. 9, p.788-796.

Sonawane, P. (2008) Non-monetary Rewards: Employee Choices \& Organizational Practices. Indian Journal of Industrial Relations, vol.44, vol.2, p.256-271.

Steers, R. M., \& Sanchez-Runde, C. 2001. Culture, motivation, and work behavior. In M. Gannon \& K. Newman (Eds.), Handbook of cross-cultural management, p.190215.London: Blackwell.

Taylor, F. (1911) Scientific management. New York: Harper. Thorndike, E. L. 1911. Animal intelligence. New York: Macmillan.

White, R. (1959) Motivation reconsidered: The concept of competence. Psychological review, vol.66, p. 297-333.

Wilson, C. (2000, July 26). More companies recognize the impact of learning centers. St. Louis Post-Dispatch, C8. 